\title{
"Impact of Demographics and Personality traits on Confidence level: Determinants of Overconfidence" (Evidence from employees and students)
}

\author{
${ }^{1}$ Dr. Taqadus Bashir, ${ }^{2}$ Safia Fazal, ${ }^{3}$ Irum Shabeer, ${ }^{4}$ Waqas Aslam, \\ ${ }^{5}$ Ghullam Jelani \\ Assistant Professor Faculty of management and administrative sciences University of Gujrat, Pakistan \\ MS SCHOLAR University of Gujrat, Pakistan \\ MS SCHOLARUniversity of Gujrat, Pakistan \\ MS SCHOLAR University of Gujrat, Pakistan \\ MS SCHOLAR University of Gujrat, Pakistan
}

\begin{abstract}
The purpose of this study is to explore the relationship among demographics, personality traits and level of confidence. The impact of this paper is twofold, one is to measure the determinants of overconfidence in employees and other is in students. This paper adopts the primary data approach, collected from employees and students through questionnaires. Two diverse populations have been selected and various statistical technique (Pearson correlation, Pearson regression, Chi-square, and Kolmogorov-Smirnov tests) are used for analysis purpose using SPSS software on a 100 sample size. Research findings shows that in employees when Openness to experience increase, overconfidence level decrease, however all remaining personality traits(conscientiousness, agreeableness, emotional stability and openness to experience) is correlated with overconfidence. In students there is no correlation between overconfidence and any of the personality traits. The regression analysis findings show that no linear relationship exists between independent and dependent variable in employees for individual personality traits except of emotional stability. Only emotional stability has a significant predictor of overconfidence among all five personality traits. However the overall personality is the significant predictor of overconfidence in employees. For students, neither individual personality traits nor overall personality has linear relationship with overconfidence.

Key Words: Behavioral Finance, Personality Traits, Level of Confidence, Demographics variables
\end{abstract}

\section{Introduction:}

Pakistan is the developing country which faces the problems of terrorism, unemployment, high inflation rate low literacy rate, unstable political conditions and many more. Total three stock exchanges exist in Pakistan which is "Karachi Stock Exchange (KSE)", "Lahore Stock Exchange (LSE)" And "Islamabad Stock Exchange (ISE)". On $14^{\text {th }}$ January 2013 Mr. Tahir ul Qadri protestation and arrest warrants of Prime Minister Causes the crash to stock exchange and decline in the prices. Prices are very much volatile in the stock exchanges of Pakistan because of the higher inflation rate and terrorism problem. Due to the problem of high inflation rate, people have fewer amounts for the investment purpose. Mostly in Pakistan people have sole proprietorship and private limited companies business and others is salaried person, having very low interest towards the investment in the stock. People mostly invest in the land and gold and confident about these investment rather than in the investment of the stock exchange. Due to the low literacy rate few people are familiar and understand the stock exchange. We targeted the Sialkot and Gujrat for this research, no doubt Sialkot is industrial city and at second place after Karachi in generating foreign remittances, but among the companies of Sialkot "Gray of Cambridge" is only listed in the KSE other are sole or partnership business. Because of these reasons there is a very low potential for investment in stock in Pakistan. However among these critical situations investors in Pakistan also prone to various behavioral biases from which one is the overconfidence bias. Standard finance theory states that individual investors are perfectly rational and wealth maximizes in their financial decisions. However the idea of fully rational investors that have perfect control on their decisions to maximize their utility is becoming less popular due to various psychological and emotional errors such as overconfidence bias which affects the ability of an investor to make a rational decision (Hayat, Bukhari, \& Ghufran, 2006). Overconfidence in its simplest way could be defined as "an inopportune belief toward a witnessed reasoning, judgment and the person's cognitive abilities" (Sadi, Ghalibaf, Rostami, Gholipour, \& Gholipour, 2011). It may be "Prediction overconfidence" i.e. very narrow confidence intervals in predictions or it may be "Certainty overconfidence" i.e. very certain in one's own judgments (Pompian, Behavioral Finance and Wealth Management, 2006). Individuals can be overconfident in a number of ways. For instance, people can overestimate their abilities or performance relative to objective, operational criteria 
(Buehler, Griffin, \& Ross, 1994; Krueger \& Wright, 2011). Alternatively, people can be overconfident by over placing themselves relative to others that is, when they believe they are better than others, even when they are not (Krueger \& Mueller, 2002; Kruger \& Dunning, 1999; Larrick et. al. 2007). The people susceptible to prediction overconfidence ignore risks associated with their investments while those who are susceptible to certainty overconfidence trade too much and maintain undiversified portfolio (Pompian, Behavioral Finance and Wealth Management, 2006). Many investors perceive themselves better than others and this tendency to think them as above average can be resulted in overconfidence bias that can ultimately lead to trade excessively (Hayat, Bukhari, \& Ghufran, 2006). During the technological bubble of 1990s investor traded too much in technological stock due to overconfidence. Investors were sure that they will be able to get super return by holding concentrated position in the technological stocks. But when this bubble burst all the gains went down (Pompian, Behavioral Finance and Wealth Management, 2006). Investors tend to be overconfident in picking stocks. This results in excessive trading volume. Investors who conduct more trades receive lower yields than the average return (Odean, 2002). People due to overconfidence bias overestimate their knowledge, underestimate risk and exaggerate their ability to control events (Nofsinger, 2002). Individuals often believe they are more talented and competent than others, even when they are not (Alicke\& Govorun, 2005; Dunning, Heath \& Suls, 2004). The propensity for overconfidence is puzzling because being able to accurately place one's abilities relative to those of others is clearly useful (Alicke, 1985; Dunning et.al.2004; Larrick, Burson, \& Soll, 2007). Overconfidence is a genuine yet flawed perception of one's own abilities (von Hippel \& Trivers, 2011). Overconfidence can persist even when the stakes are high and aligned to reward accuracy (Ehrlinger, Johnson, Banner, Dunning, \& Kruger,2008; Hoelzl \& Rustichini, 2005; Williams \& Gilovich, 2008).Personality traits and psychographic factors play an important role in determining behavior of investors and the various behavioral biases to which they are prone. Psychographics factors include gender, investor-life-cycle-stage, age, income and likewise. One of the important factors that play significant role in determining investor behavior is his or her personality (Sadi, Ghalibaf, Rostami, Gholipour, \& Gholipour, 2011). Personality traits have significant affect on investor's behavior (Maital, Filer, \& Simon, 1986). Investors' behavior will be affected by personality traits, interpretation of information, responses of sentiments, return and risk (Lin, 2011). During 2000s Michael M. Pompian and John M. Longo used Myers-Briggs Type Indicator personality test and found that investors of different gender and personality types can fall prey to various investment biases like overconfidence bias. Myers-Briggs Type Indicator (MBTI) instrument elaborated different personality types based on certain aspects of human psychology (Pompian \& Longo, 2004). According to the theory every person has innate preferences that define how he or she will behave in a certain situation (Pittenger, 1993). Big Five personality is adopted to discuss the relationship between the personality traits and investment biases because of that Big Five is most common and easy to distinguish measures. In addition, this study uses demographic variables to show the influence of investment biases. In this way, it is highly helpful and effective to easily understand the antecedent of influence what caused investment biases. Huei-Wen Lin used big five model to examine the relationship between investor's personality traits and behavioral biases. According to him certain personality traits and demographics are significantly correlated. He found that emotional stability has positive relationship with disposition effect while it has no relationship with overconfidence bias. Extroversion, openness and conscientiousness have positive relationship with disposition effect and overconfidence bias while it has no relationship with herding behavior. Finally agreeable were not susceptible to any behavioral bias (Lin, 2011). In another research Sadi, Ghalibaf, Rostami, and Gholipour correlate the behavioral biases with investor's personality traits in Tehran's Stock Market by using big five model of personality. Their findings showed that extroversion has positive relationship with hindsight bias and conscientiousness has negative relationship with randomness bias. There was a positive relationship between emotional stability and randomness bias, escalation of commitment \& availability bias. Openness has positive relationship with hindsight bias and overconfidence bias while it has negative relationship with availability bias. Finally agreeableness has no relationship with any perceptual error. (Sadi, Ghalibaf, Rostami \& Gholipour, 2011).

\section{Significance of the study:}

All those studies that have been previously done on overconfidence bias in diverse fields shows the impact of overconfidence in those fields, for instance, in clinical psychologists (Oskamp, 1965), engineers (Kidd, 1970), investment bankers (Stael von Holstein, 1972), physicians and nurses (Christensen-Szalanski and Bushyhead, 1981), In a seminal illustration of overconfidence, Svenson (1981) reported on the perception of individuals regarding their driving competence, lawyers (Wagenaar and Keren, 1986), entrepreneurs (Cooper et al., 1988), negotiators (Neale and Bazerman, 1990), People were also being found to be more confident of their predictions in fields where they have self-declared expertise (Heath and Tversky', 1991), managers (Russo and Schoemaker,1992), Alba and Hutchinson (2000) . Glaser, Langer and Weber (2005) investigated overconfidence among financial market professionals such as traders and investment bankers. All studies in above mention fields shows that though the information used for decision making was complete and without 
errors, usually brought up in results which are prone by behavioral biases some times as overconfidence and sometime by under confidence.

The research findings of this study are very helpful for understanding how demographics and personality traits effects the level of confidence not only to the investors but also to the students.

\section{Literature Review:}

Lichtenstein and Fischhoff (1977), States that the overconfidence have the tendency of decision makers to unwittingly give excessive weight to the assessment of knowledge and accuracy of information possessed and ignore the public information available.

Cooper, Folta, and Woo (1995), find that new entrepreneurs tend to seeks out more information before committing to decisions than do seasoned ones. This difference may be explained by the overconfidence trait exhibited by successful entrepreneurs. In itself, overconfidence can generally be viewed as a positive trait as it leads to survival both in short and long run, especially for entrepreneurs.

Geffert and Christensen (1998), find that women students often underestimate themselves, while their male counterparts show a tendency to overrate their own work. The present investigation suggests that the problem may not be that women necessarily lack confidence, but that, in some cases, men have too much confidence, especially when they are wrong.

Bloomsfield et. al. (1999) find that overconfidence behavior unconsciously increases prediction error thus creating adverse trading, buy stock too expensive or sell too cheap.

Alvaro and Francesco (2004) find that many subjects underestimate their health and driving risk, and that this often results in underinvestment in precautions such as insurance. Training techniques developed to reduce driving overconfidence and improve traffic safety.

Ulrike Malmendier and Geoffrey Tate (2005) find that there is a distortion in corporate investment due to CEO overconfidence. This alternative approach to measuring overconfidence, developed in the Malmendier \& Tate relies on the perceptions of the outsiders rather than the CEO's own actions.

Kufepaksi (2007) using an experimental study concludes that overconfidence behavior is a self-deception behavior that caused an error in predicting stock prices.

Grinblatt and Keloharju (2009), find that the level of trading frequency of an investor is affected by the level of investor overconfidence.

Roy Sembel \& Irwan Trinugroho,(2011), states that undergraduate student taking financial management course and artificially invest, student with the more confidence level done excessive trading than the low confidence level student. No difference in the trading among the high confidence level student after bad and good news. And decrease in trading among the low confidence level after bad and good news.

In the freshman college Amy Gustavson and H. Clark Nall (2011), find that there is no correlation between the confidence level of research and actual research skill between the students.

According to Shefrin, overconfidence "pertains to how well people understand their own abilities and the limits of their knowledge". In general, people tend to overestimate their ability to perform well.

Irwan Trinugroho (2011) describes the overconfidence and its effect on investment. By considering different variables as overconfidence, trading frequency, trading volume, bad news and return and check their impact on investment behaviors of students. The Results shows that high level of overconfidence investors take aggressive and excessive trading decisions and due to arrival of any bad news, there is no difference in the trading activity of the high overconfidence investors which ultimately decrease the investment performance so overconfidence behavior leads to too excessive transactions and excessive volumes.

According to fernandes, jose, luiz Barros (2011) companies decision making process is also affected by Cognitive biases, researcher check the impact of overconfidence and availability bias on micro and small automobiles companies and graduated students and also check the effect of overconfidence on gender, results shows that both gender groups shows overconfidence but men are more overconfident, students are also confident because of skills and knowledge and results also indicate that the higher the confidence level the lower the availability bias as more confident person does not effected by other factors as they have great believe on their own views.

Rasoul sadi( 2011) states that strong relation exist between investor's personality and perceptual errors in stock market. Research results shows that there is positive relation between extroversion and hindsight, the second hypothesis rejected which shows that there is no relationship between investor agreeableness and perceptual errors, result of third hypothesis shows that there is negative relationship between conscientiousness, fourth hypothesis shows that there is no relationship with emotional stability and fifth relation hypothesis shows that there is positive relation between openness and overconfidence bias.

Farheen Zaidi (2012) conduct research for checking the relationship between investor's personality traits, demographics and overconfidence bias, the results shows that different personalities effects differently as there is no relationship between openness and overconfidence, investors who have dutiful, responsible, emotional, full 
of energy, kind and friendly have positive relationship with overconfidence and investors those have suffered, depressed are less confident than others. On the other hand demographics result shows that the level of education and age does not affect the level

of confidence but investment experience effect a lot the level of confidence.

\section{Contribution to existing literature:}

All those above literature shows the impact of investors personality traits on their confidence level as how the enhancement of confidence ultimately effects to their investment decisions. All those prior studies take only one population for result findings. But in this study, at a time two different populations have been taken for measuring the effects of overconfidence and make a comparison between the results of both populations. Five dimensions of personality extroversion, agreeableness, emotional stability, openness to experience and conscientious have been taken for personality findings and see the relationship of these personality traits with confidence level along with the effects of demographics on confidence level not only in employees but also in students. Only emotional stability shows a significant contribution towards the overconfidence in the employees. And demographic variables like age and experience shows positive relation with overconfidence and pay scale show no relation with the overconfidence. However in case of student, personality dimensions show no relation with the overconfidence bud demographic variable age and level of education show positive relation with overconfidence level.

\section{Research Methodology:}

The type of study use for this paper is explanatory as its aim to explain the relationship between independent and dependent variables and to identify the cause and effect relationship. The objective of this study is to find out the relationship between demographics variables, personality traits and overconfidence bias.

\subsection{Population and sample:}

Two different types of population is selected that is the students and the employees who are investor, experts and specialist of investing institutions as in banks. The main aim of this diverse population is to see in depth the cause and effect relationship between demographics, personality and overconfidence bias.

The sample size use for this study is 100 . Half sample size represents to employees and half to under graduates and master level students.

\section{2 .Data gathering tool:}

This study uses the primary data for analysis because overconfidence is a behavioral aspect of human beings so it is highly effective to measure it through a survey instead of secondary data. For the purpose of data gathering two different types of questionnaires are used, one for employees and one for the students. Each questionnaire includes three parts. Part one represents the demographics of either employees or students; part two of each questionnaire contains questions that judge the level of confidence of respondents and part three contain the personality traits. 44 questions used to judge the five types of personality traits that are extroversion, agreeableness, conscientiousness, emotional stability and openness to experience.

\subsection{Validity and Reliability of data:}

For the sake of accuracy of data, the assistance of behavioral experts have been taken to remove the vagueness and errors in questions. In order to judge the reliability of data Cron Batch Alpha is used. For employees data the reliability for confidence variables is .558 and for personality is .674 . For students data the reliability for confidence variable is .563 and for personality is .543 
VI. Theoretical Framework:

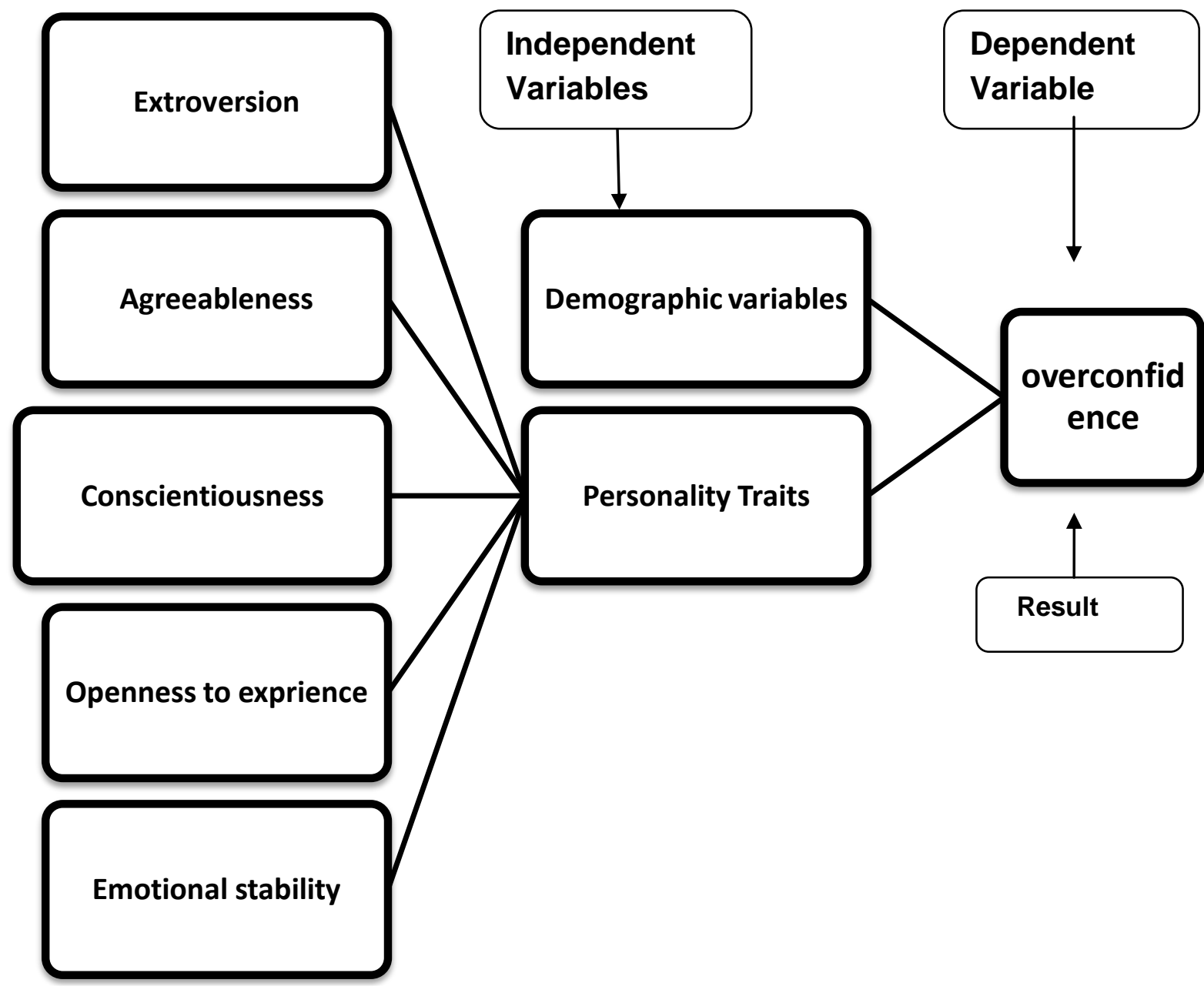

VII. Research Findings And Interpretations:

In order to find out the relationship among level of confidence, personality traits and demographics variables different diverse test are used to check in depth the relationship among these variables. These tests are Goodness of fit test (Kolmogorov-Smirnov test, Chi-Square), Pearson regression and Pearson correlation.

Goodness of fit test measure the compatibility of a random sample with theoretical probability distribution function. In order to judge the normality of sample, the Kolmogorov-Smirnov test (K-S test) which is a non parametric test is used. This test checks the normality of selected data.

7.1. K-S test results for employees: The results for the extraversion, agreeableness, conscientiousness, emotional stability and openness to experience are $.606,1.208, .910, .821, .898$ and significant values are higher than .01 and .05 which shows that data is normally distributed.

7.2. K-S test results for students: The values of the test for Extroversion, Agreeableness, conscientiousness, Emotional stability and openness to experience are $1.025, .910,0.771,0.814,0.722$ which are greater than the significance level ( higher than 0.05 ). So the data is normally distributed.

\subsection{Chi-Square test:}

Chi square applied on demographics variable because these are the attributic variables and it is used when there is a need to see the similarities between populations or variables.

H 1: "There is a relationship between Demographic variables and Overconfidence bias in employees".

7.4. Chi-Square test results for employees: Pearson chi square value for age is 14.32 at significant value of .010 and for investment experience chi square value is 27.4 at the significant value .000 which shows that there is significant association but chi square value for pay scale is 4.240 at the significant level of .392 which shows 
no significant association. Hence higher the age and investment experience people are more confident, on the other hand pay scale of the investor does not affect the confidence level but overall results of chi square test for demographical variables of employees support the hypothesis.

H1A: "There is a relationship between Demographics variables and Overconfidence bias in students".

7.5. Chi-Square test results for students: The result shows that there is significant association between student's age and overconfidence as the chi square is 62.440 with significance value of .000 . The value of Pearson chi square for level of education and investment is 6.760 with significance value .034 which also shows the significance relation between them as significance value is closer to zero and less than 0.05 so these results support the hypothesis.

\subsection{Pearson Correlation:}

It is used for studying how two things move in relation to each other. It finds the relationship between extraversion, agreeableness, conscientiousness, emotional stability and openness to experience with confidence level.

H2: "There is a relationship between employee's personality traits and Overconfidence bias".

7.7. Pearson Correlation findings for employees: The results of this study shows that openness to experience is not significantly correlated with overconfidence as the correlation value for Openness to experience is .493 which is less than significant value(0.5). On the other hand Conscientiousness correlation value is .502 , Extraversion correlation value is .512, agreeableness and emotional stability correlation values are .566 and .623 which shows significant correlation as these values are higher than standard value ( that is greater than 0.5 ) so overall results support the hypothesis.

7.8. Pearson Correlation findings for students: The result of this study shows that there is no correlation between personality traits and overconfidence as the correlation values of openness to experience is 0.172 , for Conscientiousness is .107, for Extroversion is .222, for Agreeableness is .151 and for Emotional stability is .301 which are less than their significant value (that is greater than 0.5 ) so these results are against the hypothesis.

\subsection{Pearson Regression:}

Regression analysis is used for checking the linear relationship.

H2: "There is a relationship between employee's personality traits and Overconfidence bias".

For analysis purpose the regression equation use is

$$
O C=a+b E+c A+d C+e E+f O
$$

In this equation OC (Overconfidence) is dependent variable and $\mathrm{E}$ (Extroversion), A(Agreeableness), C (contentiousness), E (Emotional Stability) and O (Openness to Experience) are independent variables. a, b, c, d, e are regression coefficients.

\subsection{Pearson regression findings for individual personality traits of employees:}

$$
\begin{aligned}
\mathrm{OC} & =\mathrm{a}+\mathrm{bE}+\mathrm{cA}+\mathrm{dC}+\mathrm{eE}+\mathrm{fO} \quad(\mathbf{E q} \ldots \mathbf{1}) \\
& =9.482+0.189 \mathrm{E}+0.217 \mathrm{~A}+0.033 \mathrm{C}+0.469 \mathrm{E}+0.112 \mathrm{O} \\
\mathrm{T} & =(1.702)(0.893)(0.855)(0.164)(2.193)(0.491) \\
\text { Sig Val } & =(.096)(.377)(.397)(.871)(.034)(.626)
\end{aligned}
$$

Regression test is not supported to the hypothesis as the "t" values of all variables is less than 1.96 which shows that independent variables are not the significant predictor of dependent variables except emotional stability as the value of $t$ for it is greater than 1.96 .

\subsection{Pearson regression findings for overall personality of employees:}

$$
\begin{aligned}
\mathrm{OC} & =\mathrm{a}+\mathrm{bP} \quad \text { (Eq...2) } \\
& =8.656+.198 \mathrm{P} \\
\mathrm{T} & =(1.766)(5.940) \\
\text { Sig Val } & =(0.084)(5.94)
\end{aligned}
$$

In the second equation where $\mathrm{P}$ covers all personality traits, regression test support the hypothesis as $\mathrm{t}$ value is greater than 1.96 which shows that the independent variable is the significant predictor of dependent variable.

H2A: "There is a relationship between student's Personality traits and Overconfidence bias". 


\subsection{Pearson regression findings for individual personality traits of students:}

$$
\begin{array}{ll}
\text { OC } & =\mathrm{a}+\mathrm{bE}+\mathrm{cA}+\mathrm{dC}+\mathrm{eE}+\mathrm{fO} \quad(\mathbf{E q} \ldots . .3) \\
\text { OC } & =26.150+0.171 \mathrm{E}-.141 \mathrm{~A}-.090 \mathrm{C}+0.165 \mathrm{E}-0.443 \mathrm{O} \\
\text { T- Values } & =(3.675)(0.678)(0.687)(0.395)(0.665)(1.857) \\
\text { Sig Val } & =(.001)(0.502)(0.496)(0.695)(0.509)(0.070)
\end{array}
$$

In the regression analysis for students this test does not support the hypothesis as $t$ value is less than 1.96 and significance level is also greater than 0.05 which shows that the independent variables are not significance predictor of dependent variable.

\subsection{Pearson regression findings for overall personality of students:}

$$
\begin{aligned}
\text { OC } & =a+b P \\
\text { OC } & =26.546+0.007 \mathrm{P} \\
\text { T-values } & =(4.016)(1.765) \\
\text { Sig Val } & =(0.065)(0.000)
\end{aligned}
$$

In the second equation there is one independent variable "p" (personality), which covers all the personality traits. The value of " $\mathrm{t}$ " is also less than 1.96 which shows that independent variable is not significant predictor of dependent variable so these results does not support the hypothesis.

\subsection{Comparison of regression findings:}

In the regression analysis for the individual personality traits the results for the student's personality shows that independent variable does not have significant predictor of dependent variable which is OC. On the other hand regression results for individual personality traits of employees shows that only emotional stability among all five personality traits has significant predictor of OC because the value of " $\mathrm{t}$ " is greater than 1.96.

In the case of overall personality, the employees regression results shows that overall personality of employees have significant predictor of Overconfidence as the value of " $\mathrm{t}$ " is 5.94 , but the results of over all students personality shows that personality does not have any significant predictor of OC as "t" value is 1.765 which is less than significant value of " $t$ ". It is concluded that employees are more prey of overconfidence bias than that of the students.

7.15. Reason: From regression analysis result it is found that employees are more prone to overconfidence bias than that of students because employees earn by own self, they have more resources, in turn they do more investment. Because of that there personality is gradually developed and then personality traits effects to their confidence level.

\section{Conclusion:}

This research examines the impact of demographic variables and personality traits on the overconfidence level of students and employees. The data is collected from students and employees through questionnaires, for computation of results different statistical techniques (Regression, correlation, chi square etc.) are used. The results of demographical variables shows that employees age and investment experience effects their confidence level and students age and level of education also have significant relation but the regression analysis shows that only employees overall personality is the significant predictor of overconfidence where as individually only emotional stability effects the employees confidence. For students neither overall personality nor individual personality traits affects to their level of confidence. In correlation analysis for students there is no relation with overconfidence and any of the personality trait, however in employees overconfidence decrease when openness to experience increase but for all the remaining personality traits overconfidence increase due to increment in those traits. It is concluded that employees personality effects their confidence level than that of the students personality as employees are self employed, they invest more for generating money which developed their personality and gradually they fall prey to different biases, among those one is the overconfidence.

\section{References:}

[1]. Geffert. \& Christensen. (1998), "Things they carry: Attitudes toward, opinions about, and knowledge of libraries and research among incoming college students".

[2]. Dittrich, Güth \& Boris. (2001). “Overconfidence in Investment Decisions An Experimental Approach”,Institute of interdisciplinary business research.

[3]. Alvaro, S. and Francesco, S. (2004). A Survey on Overconfidence, Insurance and Self-Assessment Training Programs. 
[4]. Ulrike, M. \& Geoffrey, T. (2005). "Does Overconfidence Affect Corporate Investment? CEO Overconfidence” ,Measures Revisited European Financial Management, Vol. 11, No. 5, 2005, 649-659

[5]. Hayat Bukhari \& Ghufran,(2006). "Understanding Investment Behavior Of Individual Investors: How They Handle Investment Decisions? Do They Act Rationally?"

[6]. Shefrin, \& Hersh (2007) "Behavioral Corporate Finance. Decisions that Create Value. McGraw- Hill/Irwin". New York.

[7]. Grinblatt, M., \& Keloharju, M. (2009). Sensation Seeking, Overconfidence, and Trading Activity. Journal of Finance 64(2), 549578.

[8]. Abreu, M. \& Mendes, V. (2011). “Information, Overconfidence And Trading: Do The Sources Of Information Matter?”, Working paper CMVM, vol.01.

[9]. Trinugroho, I. (2011). "Overconfidence and Excessive Trading Behavior: An Experimental Study", International Journal of Business and Management, Vol 6, No. 7

[10]. Fernandes, \& Barros, J. L. (2011). "Availability and overconfidence biases: a study over Brazilian small companies", European Journal of Management Publisher.

[11]. Sembel, R. \& Trinugroho, I. (July 2011)," Overconfidence and Excessive Trading Behavior", International Journal of Business a nd Management, Vol. 6, No. 7.

[12]. Gustavson, A. \& Freshman, C. N. ( 2011). "Overconfidence and Library Research Skills: A Troubling Relationship?" Taylor \& Francis Group, LLC.

[13]. Lin, H. (2011)," Elucidating the Influence of Demographics and Psychological Traits on Investment Biases “, World Academy of Science, Engineering and Technology.

[14]. Sadi, R (2011) "Behavioral Finance: The Explanation of Investors' Personality and Perceptual Biases Effects on Financial Decisions", International Journal of Economics and Finance.

[15]. Zaidi, F. B. (2012). "Influence of Investor's Personality Traits and Demographics on Overconfidence Bias", Institute of Interdisciplinary Business Research, Vol 4, No.6.

[16]. Moore \& Jessica, A. K. "STATUS-ENHANCEMENT ACCOUNT OF OVERCONFIDENCE", Press journal of personality and social psychology.

\section{Appendix}

Table 1:

Alpha Values

For employees:

\begin{tabular}{|l|c|}
\hline Variable & Alpha value \\
\hline Confidence level & .558 \\
\hline Extraversion & .596 \\
\hline Agreeableness & .525 \\
\hline Conscientiousness & .674 \\
\hline Emotional stability & .575 \\
\hline Openness to experience & .534 \\
\hline
\end{tabular}

For students:

\begin{tabular}{|l|c|}
\hline Variables & Alpha Value \\
\hline Confidence level & .563 \\
\hline Extraversion & .532 \\
\hline Agreeableness & .509 \\
\hline Conscientiousness & .519 \\
\hline Emotional stability & .501 \\
\hline Openness to Experience & .543 \\
\hline
\end{tabular}

For Employees:

Table 2:

\begin{tabular}{|c|c|c|c|c|c|c|}
\hline \multicolumn{7}{|c|}{ One-Sample Kolmogorov-Smirnov Test } \\
\hline & & $\begin{array}{c}\text { Extraversion } \\
\text { EM }\end{array}$ & $\begin{array}{c}\text { Agreeableness } \\
\text { _EM }\end{array}$ & $\begin{array}{c}\text { Conscientiousness } \\
\text { _EM }\end{array}$ & $\begin{array}{c}\text { Emotionalstability } \\
\text { EM }\end{array}$ & $\begin{array}{c}\text { Openness } \\
\text { EM }\end{array}$ \\
\hline \multicolumn{2}{|l|}{$\mathrm{N}$} & 50 & 50 & 50 & 50 & 50 \\
\hline \multirow[t]{2}{*}{ Normal Parameters $^{\mathrm{a}}$} & Mean & 24.1600 & 38.1000 & 27.0200 & 22.4400 & 34.5200 \\
\hline & $\begin{array}{l}\text { Std. } \\
\text { Deviation }\end{array}$ & 3.40084 & 3.90839 & 4.10321 & 3.68760 & 3.89788 \\
\hline \multirow{3}{*}{$\begin{array}{l}\text { Most } \\
\text { Differences }\end{array}$} & Absolute & .086 & .171 & .129 & .116 & .127 \\
\hline & Positive & .082 & .171 & .129 & .116 & .082 \\
\hline & Negative & -.086 & -.135 & -.126 & -.074 & -.127 \\
\hline \multicolumn{2}{|l|}{ Kolmogorov-Smirnov Z } & .606 & 1.208 & .910 & .821 & .898 \\
\hline \multicolumn{2}{|l|}{ Asymp. Sig. (2-tailed) } & .856 & .108 & .379 & .510 & .396 \\
\hline
\end{tabular}




\section{For Students:}

a. Test distribution is normal.

\begin{tabular}{|c|c|c|c|c|c|c|}
\hline \multicolumn{7}{|c|}{ One-Sample Kolmogorov-Smirnov Test } \\
\hline & & $\begin{array}{c}\text { Extroversion } \\
\text { EM }\end{array}$ & $\begin{array}{c}\text { Agreeableness } \\
\text { EM }\end{array}$ & $\begin{array}{c}\text { Conscientiousness } \\
\text { EMM }\end{array}$ & $\begin{array}{c}\text { Emotionalstability } \\
\text { EM }\end{array}$ & $\begin{array}{l}\text { Openness } \\
\text { EMM }\end{array}$ \\
\hline \multicolumn{2}{|l|}{$\mathrm{N}$} & 50 & 50 & 50 & 50 & 50 \\
\hline \multirow{2}{*}{$\begin{array}{l}\text { Normal } \\
\text { Parameters }^{\mathrm{a}}\end{array}$} & Mean & 25.0400 & 40.5400 & 27.3800 & 33.5000 & 23.1600 \\
\hline & $\begin{array}{l}\text { Std. } \\
\text { Deviation }\end{array}$ & 3.26365 & 4.41801 & 2.96847 & 3.60414 & 2.88812 \\
\hline \multirow{3}{*}{$\begin{array}{l}\text { Most } \\
\text { Extreme } \\
\text { Differences }\end{array}$} & Absolute & .145 & .129 & .109 & .115 & .102 \\
\hline & Positive & .145 & .129 & .109 & .115 & .102 \\
\hline & Negative & -.098 & -.103 & -.109 & -.066 & -.088 \\
\hline \multicolumn{2}{|c|}{$\begin{array}{l}\text { Kolmogorov-Smirnov } \\
\text { Z }\end{array}$} & 1.025 & $\mathbf{9 1 0}$ & .771 & .814 & .722 \\
\hline \multicolumn{2}{|c|}{ Asymp. Sig. (2-tailed) } & .245 & .380 & .592 & .521 & .675 \\
\hline
\end{tabular}

Table 3:

Chi-Square between Demographic Variables and Overconfidence Bias

For Employees:

\begin{tabular}{|c|c|c|c|c|}
\hline \multirow{5}{*}{ 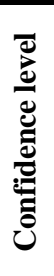 } & Demographic Variables & $\begin{array}{c}\text { Pearson Chi-Square } \\
\text { Value }\end{array}$ & Df & Significance Level \\
\hline & Gender & - & - & - \\
\hline & Age & $14.230^{\mathrm{a}}$ & 2 & .424 \\
\hline & Pay scale & $4.240^{\mathrm{b}}$ & 4 & .860 \\
\hline & Investment Experience & $27.40^{\mathrm{c}}$ & 3 & .001 \\
\hline
\end{tabular}

a. 0 cells $(.0 \%)$ have expected frequencies less than 5 . The minimum expected cell frequency is 12.5 .

b. 0 cells $(.0 \%)$ have expected frequencies less than 5 . The minimum expected cell frequency is 25.0.

c. 0 cells $(.0 \%)$ have expected frequencies less than 5 . The minimum expected cell frequency is 16.7 .

\section{For Students:}

\begin{tabular}{|c|l|c|c|c|}
\hline \multirow{4}{*}{$\begin{array}{c}\text { Confidence } \\
\text { level }\end{array}$} & $\begin{array}{c}\text { Demographic } \\
\text { Variables }\end{array}$ & $\begin{array}{c}\text { Pearson Chi-Square } \\
\text { Value }\end{array}$ & Df & $\begin{array}{c}\text { Significance } \\
\text { Level }\end{array}$ \\
\cline { 2 - 5 } & Gender & - & - & - \\
\cline { 2 - 5 } & Age & $62.440^{\mathrm{a}}$ & 2 & .000 \\
\cline { 2 - 5 } & Level of education & $6.760^{\mathrm{a}}$ & 2 & .034 \\
\hline
\end{tabular}

a. 0 cells $(.0 \%)$ have expected frequencies less than 5 . The minimum expected cell frequency is 167 .

b. 0 cells $(.0 \%)$ have expected frequencies less than 5 . The minimum expected cell frequency is 25.0.

Table 4:

Pearson Correlation between Investor's Personality Traits and Overconfidence bias

For Employees:

For Employees:
\begin{tabular}{|l|l|l|l|l|}
\hline \multirow{5}{*}{$\begin{array}{l}\text { Confidence } \\
\text { level }\end{array}$} & $\begin{array}{l}\text { Investor's } \\
\text { Personality Trait }\end{array}$ & $\begin{array}{l}\text { Correlation Coefficient ( } \\
\mathbf{r})\end{array}$ & $\begin{array}{l}\text { Significance Level ( } \\
\boldsymbol{\alpha})\end{array}$ & $\begin{array}{l}\text { Correlation Exists or } \\
\text { Not }\end{array}$ \\
\cline { 2 - 5 } & Openness & $.493^{* *}$ & .001 & Positive Correlation \\
\cline { 2 - 5 } & Consciousness & $.502^{* *}$ & .000 & Positive Correlation \\
\cline { 2 - 5 } & Extraversion & $.514^{* *}$ & .000 & Positive Correlation \\
\cline { 2 - 5 } & Agreeableness & $.566^{* *}$ & .000 & Positive Correlation \\
\cline { 2 - 5 } & Emotional stability & $.623^{* *}$ & .000 & Positive Correlation \\
\hline
\end{tabular}

**. Correlation is significant at the 0.01 level (2-tailed). 


\section{For Students:}

\begin{tabular}{|c|c|c|c|c|}
\hline \multirow{6}{*}{$\begin{array}{c}\text { Confidence } \\
\text { level }\end{array}$} & $\begin{array}{l}\text { Investor's Personality } \\
\text { Trait }\end{array}$ & $\begin{array}{l}\text { Correlation } \\
\text { Coefficient ( } r \text { ) }\end{array}$ & $\begin{array}{l}\text { Significance } \\
\text { Level }(\boldsymbol{\alpha})\end{array}$ & $\begin{array}{l}\text { Correlation } \\
\text { Exists or Not }\end{array}$ \\
\hline & Openness & $.172 * *$ & .234 & $\begin{array}{l}\text { Positive } \\
\text { Correlation }\end{array}$ \\
\hline & Consciousness & $.107 * *$ & .459 & $\begin{array}{l}\text { Positive } \\
\text { Correlation }\end{array}$ \\
\hline & Extraversion & $.222 * *$ & .122 & $\begin{array}{l}\text { Positive } \\
\text { Correlation }\end{array}$ \\
\hline & Agreeableness & $.151 * *$ & .295 & $\begin{array}{l}\text { Positive } \\
\text { Correlation }\end{array}$ \\
\hline & Emotional stability & $.301 * *$ & .034 & $\begin{array}{l}\text { Positive } \\
\text { Correlation }\end{array}$ \\
\hline
\end{tabular}

*. Correlation is significant at the 0.05 level (2-tailed).

**. Correlation is significant at the 0.01 level (2-tailed). 